\title{
Public health implications of heavy metals in foods and drinking water in Ethiopia (2016 to 2020): systematic review
}

Dechasa Adare Mengistu(D

\begin{abstract}
Background: Besides their benefits, heavy metals are toxic, persistent, and hazardous to human health, even at their lower concentrations. Consumption of unsafe concentrations of food contaminated with heavy metals may lead to the disruption of numerous biological and biochemical processes in the human body. In developing country including Ethiopia, where untreated or partially treated wastewater is used for agricultural purposes, the problems related to the consumption foods contaminated with heavy metals may poses highest risk to human health. Therefore, this review was aimed to determine the public health implications of heavy metals in foods and drinking water in Ethiopia.

Methods: The articles published from 2016 to 2020 were identified through systematic searches of electronic databases that include MEDLINE/PubMed, EMBASE, CINAH, Google Scholar, WHO, and FAO Libraries. The data was extracted using a predetermined data extraction form using Microsoft Excel, 2016. The methodological quality of the included studies was assessed using mixed methods appraisal tool (MMAT) version 2018 and Joanna Briggs Institute Critical Appraisal tools to determine the relevance of the studies. Finally, the results were evaluated based on the FAO/WHO guidelines for foods and drinking water.
\end{abstract}

Results: A total of 1019 articles published from 2016 to 2020 were searched from various electronic databases and by manual searching on Google. Following the initial screening, 317 articles were retrieved for evaluation and 49 articles were assessed for eligibility, of which 21 studies were included in the systematic review. The mean concentration of $\mathrm{Cr}, \mathrm{Cd}, \mathrm{Pb}, \mathrm{As}, \mathrm{Hg}, \mathrm{Zn}, \mathrm{Cu}, \mathrm{Ni}, \mathrm{Co}, \mathrm{Fe}$ and $\mathrm{Mn}$ in fruits and vegetables ranged from 2.068-4.29, 0.86$1.37,1.90-4.70,1.01-3.56,3.43-4.23,19.18-98.15,4.39-9.42,1.037-5.27,0.19-1.0,199.5-370.4,0.26-869$ mg/kg, respectively. The mean concentration $\mathrm{Cr}, \mathrm{Cd}, \mathrm{Pb}, \mathrm{As}, \mathrm{Zn}$, and $\mathrm{Fe}$ in meat and milk ranged from 1.032-2.72, 0.233$0.72,1.32-3.15,0.79-2.96,78.37-467.7$, and $505.61-3549.9 \mathrm{mg} / \mathrm{kg}$, respectively. The mean concentration of $\mathrm{Cr}, \mathrm{Cd}$, $\mathrm{Pb}, \mathrm{Zn}$, and $\mathrm{Cu}$ in drinking water ranged $0.0089-0.054,0.02-0.0237,0.005-0.369,0.625-2.137$, and $0.176-1.176 \mathrm{ml} / \mathrm{L}$, respectively. The mean concentration of $\mathrm{Cr}, \mathrm{Cd}, \mathrm{Pb}, \mathrm{Zn}, \mathrm{Cu}, \mathrm{Ni}, \mathrm{Co}, \mathrm{Fe}$, and $\mathrm{Mn}$ in other edible cereals ranged from $0.973-2.165,0.424-0.55,0.65-1.70,70.51-81.58,14.123-15.98,1.89-13.8,1.06-1.59,67.866-110.3$, and 13.686-15.4 $\mathrm{mg} / \mathrm{kg}$, respectively.

Correspondence: Dechasa.Adare@haramaya.edu.et

Department of Environmental Health, College of Health and Medical Science,

Haramaya University, Harar, Ethiopia

C C The Author(s). 2021 Open Access This article is licensed under a Creative Commons Attribution 4.0 International License, which permits use, sharing, adaptation, distribution and reproduction in any medium or format, as long as you give appropriate credit to the original author(s) and the source, provide a link to the Creative Commons licence, and indicate if changes were made. The images or other third party material in this article are included in the article's Creative Commons licence, unless indicated otherwise in a credit line to the material. If material is not included in the article's Creative Commons licence and your intended use is not permitted by statutory regulation or exceeds the permitted use, you will need to obtain permission directly from the copyright holder. To view a copy of this licence, visit http://creativecommons.org/licenses/by/4.0/. The Creative Commons Public Domain Dedication waiver (http://creativecommons.org/publicdomain/zero/1.0/) applies to the data made available in this article, unless otherwise stated in a credit line to the data. 
Conclusion: This systematic review identified heavy metals in foods and drinking water and determined their public health implications. The results of this finding imply that the majority of the studies reported high concentrations of toxic heavy metals in foods and drinking water that are hazardous to human health. Therefore, effective food safety and risk-based food quality assessment are essential to protect the public health.

Keywords: Public health, Heavy metals, Food safety, Drinking water, Health implication, Ethiopia

\section{Introduction}

Heavy metals are metallic chemicals with a relatively high density that are toxic, persistent and hazardous to human health at low concentrations [1]. These include mercury $(\mathrm{Hg})$, lead $(\mathrm{Pb})$, copper $(\mathrm{Cu})$, cadmium $(\mathrm{Cd})$, arsenic (As), chromium (Cr), thallium (TI), manganese $(\mathrm{Mn})$, zinc $(\mathrm{Zn})$, and nickel $(\mathrm{Ni})$ [2]. Some of these metals ( $\mathrm{Fe}, \mathrm{Mn}, \mathrm{Cu}$ and $\mathrm{Zn}$ ) are essential for metabolism in their lower concentrations [3]. As, Cd, Cr, Co, Pb, $\mathrm{Ni}$, and $\mathrm{Zn}$ are the most common heavy metals potentially hazardous to human health [4]. However, cadmium and lead have more significant side effects on human health since they are easily accessible through the food chain $[5,6]$.

Consumption of unsafe concentrations of heavy metals in food may lead to the disruption of biological and biochemical processes in the human body [7]. These disorders are characterized by gastrointestinal disorders, stomatitis, tremors, diarrhea, hemoglobinuria, paralysis, vomiting, convulsions, and depression [8]. Similarly, heavy metals have the ability to disrupt metabolic activity and genetic makeup, or to affect embryonic or fetal development [9].

Currently, waste water is used for agricultural purposes in many countries of the world. At least 20 million hectares of land are irrigated with untreated or partially treated wastewater that poses the highest risk to the environment and human health $[10,11]$. However, the problem is more severe in developing countries where reusing waste water for agricultural purposes is increasing from time to time [12]. This leads to the uptake and accumulation of various metals in foods and potential risks to human health $[13,14]$.

Therefore, food safety is an important public health issue, and is necessary to maintain food quality and to ensure that human beings are safe from food related health hazards $[15,16]$. In many urban areas of Ethiopia, a large volume of untreated waste water is released into water bodies that are used for irrigation or agricultural purposes and has significant negative impacts on human health and the environment [17]. Besides these problems, there is no adequate country-wide knowledge base of the public health implications of heavy metals in foods and drinking water in Ethiopia.

Thus, this review aimed to determine the public health implications of heavy metals in foods and drinking water in Ethiopia that can be crucial to understand its implications, to take the appropriate measures by the concerned organizations, and to protect the public health.

\section{Eligibility criteria}

The articles meeting the following criteria were included in the systematic review: -

- Study area: Research articles conducted in Ethiopia

- Study design: Cross-sectional studies

- Language: Articles published in English language

- Population: Articles conducted on any type of food and drinking water.

- Publication issue: Full text articles published in peer-reviewed journals from 2016 to 2020.

- Outcome: Articles reported the quantitative outcome of any heavy metals.

\section{Sources of information and search strategy}

The original articles published from 2016 to 2020 were identified through the systematic searches of various electronic databases that include MEDLINE/PubMed, EMBASE, CINAH, Google Scholar, WHO, and FAO Libraries. Initially, the author (DA. Mengistu) conducted the search on the MEDLINE, followed by searching for the articles across the included electronic databases using the identified keywords, Medical Subject Headings (MeSH terms) and index terms. The following is a search term the author (DA. Mengistu) used in the initial search from PubMed: ((“"Public health” [MeSH Terms] OR ("public"[All Fields] AND "health"[All Fields]) OR "public health"[All Fields]) AND ("implication" [MeSH Terms] OR "implication"[All Fields] OR "implications"[All Fields])) OR (“"public health" [MeSH Terms] OR ("public"[All Fields] AND "health"[All Fields]) OR "public health"[All Fields]) AND ("risk"[$\mathrm{MeSH}$ Terms] OR "risk"[All Fields] OR "risks"[All Fields])) OR (("public health"[MeSH Terms] OR ("public"[All Fields] AND "health"[All Fields]) OR "public health"[All Fields]) AND hazards [All Fields])) OR (("public health"[MeSH Terms] OR ("public"[All Fields] AND "health"[All Fields]) OR ("public health"[All Fields]) AND problems [All Fields])) AND (("heavy metal"[MeSH Terms] OR ("heavy"[All Fields] AND "metal"[All Fields]) OR "heavy metal "[All Fields])) AND (“food"[MeSH Terms] OR "food"[All Fields] OR 
("drinking water" [MeSH Terms] OR (“drinking”[All Fields] AND "water"[All Fields]) OR " drinking water"[All Fields])) AND ("Ethiopia”[All Fields]))).

The search strategy from Embase was as follows: (1) 'public health' OR 'public health'/exp. OR 'health' OR 'health'/exp. OR 'implication' OR 'implication'/exp. OR 'risk' OR 'risk'/exp. OR 'heavy metal' OR 'heavy metal'/ exp. OR 'trace metal "food' OR 'food'/exp. OR 'water supply' OR 'water supply'/exp. OR 'drinking water' OR 'drinking water/exp' OR 'meat' OR 'meat'/exp. OR 'fish' OR 'fish'/exp. OR 'cereals' OR 'cereals'/exp.

Furthermore, manual searching of the articles was done to get additional studies relevant to this study.

\section{Study selection}

All articles searched from various electronic databases were exported to ENDNOTE software version X5 (Thomson Reuters, USA). Duplicated articles were removed using the EndNote. Articles were screened by the author based on their titles and abstracts. Then, full-text articles were assessed against the inclusion criteria to determine their relevance to the study.

\section{Data extraction and quality assessment}

The data were extracted from the included articles using a predetermined data extraction form, using Microsoft Excel 2016. The data regarding the author, year of publication, study area, study design, sample size, and outcome were extracted from the included articles. The extracted data was presented in the form of a table and text along with the main findings (concentration of heavy metals in foods and drinking water), types of foods, study location, and publication year.

The methodological quality of the included articles was evaluated using the mixed methods appraisal tool (MMAT) version 2018 [18] and Joanna Briggs Institute (JBI) Critical Appraisal tools [19]. These appraisal tools have the following nine evaluation criteria/ parameters; (1) appropriate sampling frame; (2) proper sampling technique; (3) adequate sample size; (4) study subject and setting description; (5) sufficient data analysis; (6) use of valid methods for the identified conditions; (7) valid measurement for all participants; (8) using appropriate statistical analysis, and (9) adequate response rate. The mean score was taken across all included studies and graded as high ( $80 \%$ and above score), moderate (60-80\% score), and low ( $<60 \%$ score) quality. Each included article was subjected to an evaluation (appraisal), at least three times at different time periods to check the accuracy of the work and to reduce errors. Finally, the articles meeting the inclusion criteria were included in the study.

\section{Outcome measures}

The outcome of this systematic review aimed to determine the public health implications of heavy metals in foods and drinking water. The overall mean concentration of each heavy metal was calculated across the included articles. Finally, the concentration of each heavy metal was evaluated against Food and Agricultural Organization (FAO) and World Health Organization (WHO) guidelines developed for foods and drinking water.

\section{Results}

\section{Study selection}

One thousand and nineteen published articles, abstracts, editorial papers, and reports were identified from various electronic databases. Nine hundred and ninety-eight articles were searched from electronic databases while 21 were searched manually from the Google. Among these articles, 741 were searched from PubMed, 92 from MEDLINE, 102 from EMBASE, 11 from CINAHL, 22 from Scopus, nine from the Web of Science, 14 from Google Scholar, seven articles from other electronic databases and 21 articles through manual searching. Following the initial screening, 317 articles were retrieved for evaluation and 49 articles were assessed for eligibility, of which 21 studies were included in the systematic review (Fig. 1).

\section{Characteristics of the included studies}

A total of 21 articles conducted in Ethiopia and aimed to determine the concentration of heavy metals in any type of food and drinking water, and meet the inclusion criteria were included in the study.

Of 21 articles included in this systematic review, 6(28.57\%) studies conducted in Oromia region [20-25], 5(23.8\%) in Amhara region [25-29], 3 (14.29\%) in Tigray [30-32], 2(9.5) \%) in Southern Nations, Nationalities, and Peoples' (SNNP) [33, 34], 1(4.76\%) in Addis Ababa [35], 1(4.76\%) in Harari [36], and 3 (14.29\%) studies conducted in unspecific area (one in and around Addis Ababa [37]; one in Oromia and Addis Ababa [38] and one unspecified; conducted in Ethiopia) [39].

On the other hand, 5 (23.8\%) studies conducted on vegetables alone [20, 21, 23, 36, 37], while one study included both fruit and vegetables [22]. Three (14.29\%) and $3(14.29 \%)$ studies were conducted to determine the concentration of heavy metals in drinking water [31, 32, $34]$ and fruit [26, 33, 39], respectively.

Furthermore, 2(9.5\%) articles [25] were conducted to determine the concentration of heavy metals in fish tissue. Seven (33.3\%) articles (one article on each of edible mushrooms [24]; milk [40]; honey [38]; barley [27]; popcorn and cornflakes [35]; sesame seeds [30]; and raw and roasted seeds and bread [28]) were conducted to 


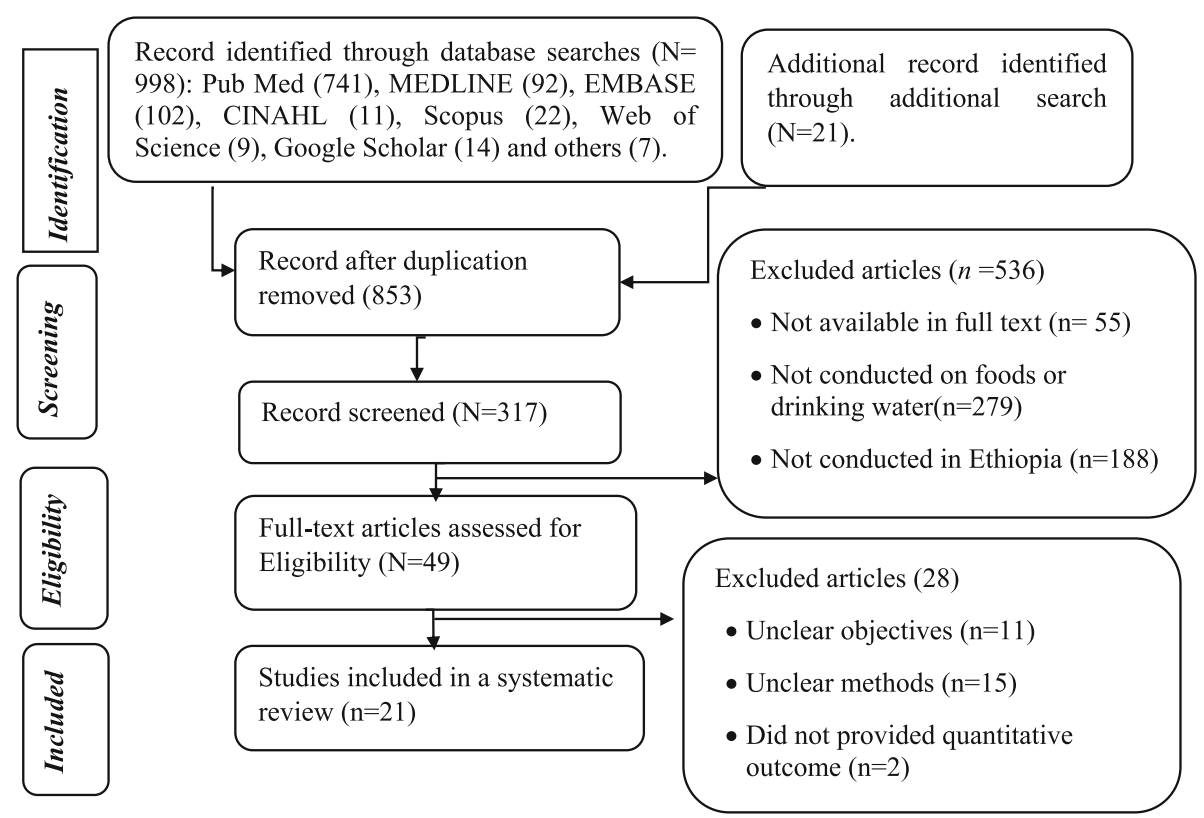

Fig. 1 PRISMA flow diagram indicating the selection process of included articles for a systematic review, 2020

determine the concentration of heavy metals in various raw and processed foods. Furthermore, among the included articles [20-40], 7 (33.3\%) and 5 (23.8\%) were published in 2020 [21, 26, 27, 29, 31, 33, 36] and in 2019 [20, 23, 25, 30, 32] respectively. (See Table 1 for details). All studies were cross-sectional studies. Almost all common toxic or hazardous heavy metals were included in the study. Similarly, the articles graded as high quality (having an $80 \%$ or above score) were included in this study.

\section{Concentration of heavy metals in foods and drinking water}

The mean concentration of $\mathrm{Cr}, \mathrm{Cd}, \mathrm{Pb}, \mathrm{As}, \mathrm{Hg}, \mathrm{Zn}, \mathrm{Cu}$, $\mathrm{Ni}, \mathrm{Co}, \mathrm{Fe}$ and $\mathrm{Mn}$ in fruits and vegetables ranged from 2.068-4.29, 0.86-1.37, 1.90-4.70, 1.01-3.56, 3.43-4.23, $19.18-98.15,4.39-9.42,1.037-5.27,0.19-1.0,199.5-$ $370.4,0.26-869 \mathrm{mg} / \mathrm{kg}$, respectively. The mean concentration $\mathrm{Cr}, \mathrm{Cd}, \mathrm{Pb}, \mathrm{As}, \mathrm{Zn}$, and $\mathrm{Fe}$ in meat and milk ranged from 1.032-2.72, 0.233-0.72, 1.32-3.15, 0.79$2.96,78.37-467.7$, and $505.61-3549.9 \mathrm{mg} / \mathrm{kg}$, respectively. The mean concentration of $\mathrm{Cr}, \mathrm{Cd}, \mathrm{Pb}, \mathrm{Zn}$, and $\mathrm{Cu}$ in drinking water ranged 0.0089-0.054, 0.02-0.0237, $0.005-0.369,0.625-2.137$, and $0.176-1.176 \mathrm{mg} / \mathrm{L}$, respectively. The mean concentration of $\mathrm{Cr}, \mathrm{Cd}, \mathrm{Pb}, \mathrm{Zn}, \mathrm{Cu}, \mathrm{Ni}$, $\mathrm{Co}, \mathrm{Fe}$, and $\mathrm{Mn}$ in other types of foods ranged from 0.973$2.165,0.424-0.55,0.65-1.70,70.51-81.58,14.123-15.98$, $1.89-13.8,1.06-1.59,67.866-110.3$, and $13.686-15.4 \mathrm{mg} / \mathrm{kg}$, respectively. Similarly, the study found the mean concentration of $\mathrm{Cr}, \mathrm{Cd}, \mathrm{Pb}, \mathrm{Zn}, \mathrm{Cu}, \mathrm{Ni}, \mathrm{Co}, \mathrm{Fe}$, and $\mathrm{Mn}$ ranged from 0.0012-0.0043, ND-0.0069, ND, 0.00192-0.00422, 0.00009-
0.00047, 0.0008-0.00446, 0.0006-0.00117, 0.00537-0.0124, and $0.00016-0.00089 \mathrm{mg} / \mathrm{kg}$, respectively (Table 1 ).

\section{Discussion}

Heavy metal concentration in foods and drinking water Humans are exposed to heavy metals through various pathways [41]. Among these pathways, consumption of food contaminated with heavy metals is a major route for human exposure to heavy metals [42]. In the current study, the overall mean concentration of heavy metals was taken across the included studies, depending on the types of foods and drinking water. Besides their benefits, consumption of food contaminated with heavy metals may pose a risk to the health of humans. For example, chromium plays a major role in maintaining blood glucose levels within its recommended limits, but beyond that, it is toxic and hazardous to human health [43]. The current study found the mean concentration of $\mathrm{Cr}$ in fruits and vegetables, and drinking water ranged from $2.068-4.29 \mathrm{mg} / \mathrm{kg}$, and $0.0089-0.054 \mathrm{mg} / \mathrm{L}$, respectively that was higher than the maximum allowable limit of $\mathrm{Cr}$ in fruits and vegetables $(2.3 \mathrm{mg} / \mathrm{kg})$ [44], and drinking water $(0.05 \mathrm{mg} / \mathrm{L})[31,45,46]$. This may be as the result of using an untreated or partially treated industrial waste water discharged to the environment which can contaminate the water supply.

Similarly, excessive lead exposure can cause adverse health effects such as hypertension, gastrointestinal effects, retarded growth, nervous system dysfunction, cognitive disability, hearing loss, and effects on reproduction [47]. However, the current study found the mean concentration 
Table 1 Overall characteristics of included articles, 2020

\begin{tabular}{|c|c|c|c|c|c|}
\hline Authors & Year & Region & Samples & Heavy metal concentration & $\begin{array}{l}\text { Risk } \\
\text { of } \\
\text { bias }\end{array}$ \\
\hline Bahiru et al & 2019 & Oromia & Vegetable & $\begin{array}{l}\text { The concentration of } \mathrm{Cr}, \mathrm{Cd} \text { and } \mathrm{Pb} \text { in vegetable ranged from } 2.90- \\
3.77,2.20-3.68 \text { and } 4.60-5.50 \mathrm{mg} / \mathrm{kg} \text {, respectively. }\end{array}$ & Low \\
\hline $\begin{array}{l}\text { Gebeyehu } \\
\text { and Bayissa }\end{array}$ & 2020 & Oromia & Vegetable & $\begin{array}{l}\text { The concentration of } \mathrm{As}, \mathrm{Pb}, \mathrm{Cd}, \mathrm{Cr} \text { and } \mathrm{Hg} \text { in vegetable ranged from } \\
1.93-5.73,3.63-7.56,0.56-1.56,1.49-4.63 \text { and } 3.43-4.23 \mathrm{mg} / \mathrm{kg} \text {, } \\
\text { respectively. }\end{array}$ & Low \\
\hline $\begin{array}{l}\text { Gezahegn } \\
\text { et al }\end{array}$ & 2017 & $\begin{array}{l}\text { In and } \\
\text { around } \\
\text { Addis } \\
\text { Ababa }\end{array}$ & Leaf vegetables & $\begin{array}{l}\text { The concentration of } \mathrm{Zn}, \mathrm{Cu}, \mathrm{Ni}, \mathrm{Co}, \mathrm{Fe}, \mathrm{Mn}, \mathrm{Cr} \text {, As and } \mathrm{Pb} \text { in leaf } \\
\text { vegetables ranged from } 10.9-219.3,1.5-11.6,0.7-11.6,0.3-0.47,40.8- \\
193.6,0.26-868.5,1.7-8.8,0.09-1.40 \text { and } 0.5-12.3 \mathrm{mg} / \mathrm{kg} \text {, respectively. }\end{array}$ & Low \\
\hline Marga & 2016 & Oromia & $\begin{array}{l}\text { Fruit and } \\
\text { vegetables }\end{array}$ & $\begin{array}{l}\text { The concentration of } \mathrm{Pb}, \mathrm{Cd}, \mathrm{Cu}, \mathrm{Zn}, \mathrm{Co} \text { and } \mathrm{Ni} \text { in fruit and vegetables } \\
\text { ranged from } 0.14-0.31, \mathrm{ND}-0.07,1.29-6.44,1.02-17.68,0.08-1.54 \text { and } \\
0.39-2.20 \mathrm{mg} / \mathrm{kg} \text {, respectively. }\end{array}$ & Low \\
\hline $\begin{array}{l}\text { Bahiru and } \\
\text { Teju }\end{array}$ & 2019 & Oromia & Vegetable & $\begin{array}{l}\text { The concentration of Fe, } \mathrm{Zn} \text { and Cu ranged from } 358.17-547.17,45.63- \\
62.46 \text {, and } 10.20-15.07 \mathrm{mg} / \mathrm{kg} \text {, respectively. }\end{array}$ & Low \\
\hline Alamnie et al & 2020 & Harari & $\begin{array}{l}\text { Green Leafy } \\
\text { Vegetable }\end{array}$ & $\begin{array}{l}\text { The mean concentration of } \mathrm{Pb}, \mathrm{Cd} \text { and } \mathrm{Cr} \text { in vegetable were } 0.17,0.62 \\
\text { and } 1.78 \mathrm{mg} / \mathrm{kg} \text {, respectively. }\end{array}$ & Low \\
\hline
\end{tabular}

Haile et al

Wild edible plants (unspecified) (fruit)

Babuskin et al 2020 SNNP Fruit

Adefa and 2020 Amhara
Tefera
$\begin{aligned} & \text { Shitahun and } 2020 \text { Amhara oleifera } \\ & \text { Tessema }\end{aligned}$

Abebe, et al 2017 Addis Popcorn and Ababa cornflakes

Gebrekidan \& 2019 Tigray $\quad$ Sesame seeds Desta

Abebe and 2017 Amhara Chandravanshi

Raw seeds and roasted seeds and bread

Gebrelibanos 2016 Oromia et al

Kindie et 2020 Amhara Fish

Gure et al 2019 Oromia_ Fish

Akele et al. 2017 Amhara Milk
The concentrations of $\mathrm{Cu}, \mathrm{Pb}, \mathrm{Cd}, \mathrm{Ni}$, and $\mathrm{Cr}$ in wild edible plants (fruit) Low were $4.57,2.37,0.93,2.02$, and $2.47 \mathrm{mg} / \mathrm{kg}$, respectively.

The concentration of $\mathrm{Zn}, \mathrm{Cd}, \mathrm{Cu}, \mathrm{Co}, \mathrm{Pb}, \mathrm{Cr}, \mathrm{Ni}$ and $\mathrm{Mn}$ in fruit ranged Low from 1.3-6.3, ND-0.001, 0.44-6.2, 0.02-0.31, ND-0.008, ND-0.09, 0.12-8.8, $1.3-31 \mathrm{mg} / \mathrm{kg}$, respectively.

The concentration of $\mathrm{Cr}$, Cu and $\mathrm{Zn}$ in moringa oleifera was 6.675, 7.9 Low and $42.75 \mathrm{mg} / \mathrm{kg}$ respectively. $\mathrm{Pb}$ and $\mathrm{Cd}$ were below the detection limit.

The concentration of $\mathrm{Zn}, \mathrm{Fe}, \mathrm{Ni}, \mathrm{Mn}, \mathrm{Cu}, \mathrm{Cr}, \mathrm{Co}, \mathrm{Pb}$, and $\mathrm{Cd}$ in barley ranged from 33.7 to $76.7,15.7$ to $106,3.78$ to $27.6,8.83$ to $13.7,5.83$ to $10.5,4.33$ to $6.11,3.38$ to $5.83,1.44$ to 2.33 , and 0.98 to $1.55 \mathrm{mg} / \mathrm{kg}$, respectively.

The concentration of $\mathrm{Cr}, \mathrm{Mn}, \mathrm{Fe}, \mathrm{Co}, \mathrm{Cu}, \mathrm{Zn}$ and $\mathrm{Pb}$ in the popcorn was Low $0.68,6.17,9.5,1.41,0.09,88.3$ and 0.94 , respectively. The concentration of $\mathrm{Cr}, \mathrm{Mn}, \mathrm{Fe}, \mathrm{Co}, \mathrm{Cu}, \mathrm{Zn}$, and $\mathrm{Pb}$ in cornflakes was 0.30, 3.0, 5.5, 0.32, $0.30,40.7$ and $0.36 \mathrm{mg} / \mathrm{kg}$, respectively. $\mathrm{Cd}$ and $\mathrm{Ni}$ were not ND.

The concentration of $\mathrm{Fe}, \mathrm{Zn}, \mathrm{Cu}, \mathrm{Cd}$, and $\mathrm{Pb}$ in sesame seeds ranged Low from 35.5-43.1, 58.1-67.0, 15.3-21.3, 0.202-0.262, and 0.08-0.114 mg/kg, respectively.

The concentration of $\mathrm{Cr}$ ranged from $0.17-1.58,0.18-1.72$ and $0.18-\quad$ Low 1.65; $\mathrm{Mn}$ from 1.04-3.98, 1.09-4.60 and 0.52-2.83; Fe from 18.0-115, 16.5-103, and 45.3-146; Co from 0.41-0.49, 0.50-0.76, and 0.34-0.75; Cu from $0.04-0.32,0.04-2.72$, and $0.05-3.12 ; \mathrm{Zn}$ from 61.7-77.6, 59.2-83.0, and 108-116; Pb from 0.31-2.59, 0.82-3.11, 1.55-3.41 mg/kg for raw seed, roasted seed, and bread, respectively.

Edible Mushroom The following concentration ( $\mathrm{mg} / \mathrm{kg}$ )of heavy metals was reported in Low [24] edible mushroom (Pleurotus ostreatus); Cu (51.19), Fe (220.87), Zn (89.68) and $\mathrm{Mn}(47.55 \mathrm{mg} / \mathrm{kg})$.

The following concentration $(\mathrm{mg} / \mathrm{kg}$ ) of heavy metals was reported in edible mushroom (Pleurotus florida): Cu (53.56), Fe (243.92), Zn (95.26) and $\mathrm{Mn}(41.29 \mathrm{mg} / \mathrm{kg})$. Cd and $\mathrm{Pb}$ were not detected.

The concentration $(\mathrm{mg} / \mathrm{kg})$ of $\mathrm{As}, \mathrm{Cd}, \mathrm{Cr}, \mathrm{Zn}$, and Fe in the muscle ranged from ND- 0.98, ND-0.19, 0.08-2.83, 6.53-627.08, and 14.23$164.77 \mathrm{mg} / \mathrm{kg}$, respectively. Lead was not detected. The concentration $(\mathrm{mg} / \mathrm{kg}$ ) of $\mathrm{As}, \mathrm{Cd}, \mathrm{Cr}, \mathrm{Zn}$ and Fe in the liver ranged from 1.58-4.94, 0.7-1.63, 2.65-6.12, 1.95-4.5, 227.38-769.67, and 997.0$6935.0 \mathrm{mg} / \mathrm{kg}$, respectively.

The concentration of $\mathrm{Cr}, \mathrm{Pd}, \mathrm{Cd}, \mathrm{Cu}$, and $\mathrm{Co}$ in fish tissue was 11.1, 7.57, Low $0.65,7.7$, and $4.1 \mathrm{mg} / \mathrm{kg}$, respectively.

The concentration of $\mathrm{Cr}, \mathrm{Mn}, \mathrm{Cu}, \mathrm{Zn}, \mathrm{Cd}$, and $\mathrm{Pb}$ in milk ranged from $0.468-0.828,1.614-2.806,0.840-1.532,1.208-5.267$, ND-0.330, and ND- 
Table 1 Overall characteristics of included articles, 2020 (Continued)

\begin{tabular}{|c|c|c|c|c|c|c|}
\hline Authors & Year & Region & Samples & Heavy metal concentration & $\begin{array}{l}\text { Risk } \\
\text { of } \\
\text { bias }\end{array}$ & Reference \\
\hline & & & & $0.186 \mathrm{mg} / \mathrm{L}$, respectively. & & \\
\hline $\begin{array}{l}\text { Haftu \& } \\
\text { Sathishkumar }\end{array}$ & 2020 & Tigray & Drinking Water & $\begin{array}{l}\text { The concentration of } \mathrm{Cd} \text { in drinking water ranged from } 0.00125-0.011 \text {, } \\
\mathrm{Pb} \text { from } 0.008-1.10, \mathrm{Cu} \text { from } 0.515-3.515, \mathrm{Zn} \text { from } 0.785-5.32, \mathrm{Cr} \text { from } \\
0.015-0.15 \text {, Fe from } 0.11-1.3 \text {, and Ni from } 0.017-0.455 \mathrm{mg} / \mathrm{L}\end{array}$ & Low & {$[31]$} \\
\hline Desalegn et al & 2018 & SNNP & Drinking Water & $\begin{array}{l}\text { The concentration of } \mathrm{Cr} \text { in drinking water ranged from 0.004-0.006 } \\
\mathrm{mg} / \mathrm{L} \text {. While } \mathrm{Cr} \text { and } \mathrm{Zn} \text { accounted } 0.0036 \text { and } 0.599 \mathrm{mg} / \mathrm{L} \text {, respectively. } \\
\mathrm{Cu}, \mathrm{Pb} \text {, and } \mathrm{Cd} \text { were not detected in drinking water. }\end{array}$ & Low & [34] \\
\hline Ododo & 2019 & Tigray & Drinking Water & $\begin{array}{l}\text { The concentration of } \mathrm{Cd}, \mathrm{Co}, \mathrm{Cr}, \mathrm{Cu}, \mathrm{Fe}, \mathrm{Mn}, \mathrm{Ni}, \mathrm{Pb} \text {, and } \mathrm{Zn} \text { was } 0.006 \text {, } \\
0.015,0.008,0.013,0.243,0.228,0.022,0.007 \text { and } 0.492 \mathrm{mg} / \mathrm{L} \text {, } \\
\text { respectively. }\end{array}$ & Low & [32] \\
\hline $\begin{array}{l}\text { Yohannes } \\
\text { et al }\end{array}$ & 2018 & $\begin{array}{l}\text { Addis } \\
\text { Ababa and } \\
\text { Oromia }\end{array}$ & Honey & $\begin{array}{l}\text { The concentration of Fe in honey samples ranged from } 5.37-12.4, \mathrm{Ni} \\
\text { from } 0.80-4.46, \mathrm{Cr} \text { from } 1.20-4.33, \mathrm{Zn} \text { from } 1.92-4.22, \mathrm{Co} \text { from } 0.60- \\
1.17, \mathrm{Mn} \text { from } 0.16-0.89, \mathrm{Cd} \text { from ND-0.69, and Cu from } 0.09-0.47 . \mathrm{Pb} \\
\text { was not detected. }\end{array}$ & Low & [38] \\
\hline
\end{tabular}

Keys: ND Not Detected, SNNP Southern Nation Nationality and People

of $\mathrm{Pb}$ in fruit and vegetables, edible cereals, fish and meat and drinking water ranged from $1.90-4.70 \mathrm{mg} / \mathrm{kg}, 0.65-$ $1.70 \mathrm{mg} / \mathrm{kg}, 1.32-3.15 \mathrm{mg} / \mathrm{kg}$, and $0.005-0.369 \mathrm{mg} / \mathrm{L}$, respectively. These results were higher than the maximum allowable concentration of $\mathrm{Pd}$ in fruit and vegetables ranged from 0.05 to $0.3 \mathrm{mg} / \mathrm{kg}$ [44], $0.2 \mathrm{mg} / \mathrm{kg}$ in cereal grains [44], $0.3 \mathrm{mg} / \mathrm{kg}$ in fish [44], and $0.01 \mathrm{mg} / \mathrm{L}$ in natural water [48].

Cadmium accumulates in the human body, especially in the kidneys, and can damage the kidney [49]. The mean $\mathrm{Cd}$ concentration in drinking water ranged from 0.02-0.0237 mg/L, which was higher than the FAO/ WHO, 2011 guidelines $(0.003 \mathrm{mg} / \mathrm{L})$ [44]. Furthermore, the mean concentration of $\mathrm{Cd}$ in fruit and vegetables ranged from $0.86-1.37 \mathrm{mg} / \mathrm{kg}$, which was higher than the maximum permitted limit $(0.05-0.1 \mathrm{mg} / \mathrm{kg})$ [44].

Furthermore, the study found that the overall mean concentration of $\mathrm{Cu}$ in fruits and vegetables ranged from $4.39-9.42 \mathrm{mg} / \mathrm{kg}$, which was lower than the maximum permissible level ranged from $4.5 \mathrm{mg} / \mathrm{kg}$ in fruit and [50] and $40 \mathrm{mg} / \mathrm{kg}$ in vegetables $[44,51]$. Similarly, the concentration of $\mathrm{Cu}$ in drinking water ranged from $0.176-1.176 \mathrm{mg} / \mathrm{L}$, which was lower than the maximum permissible limit $(2.0 \mathrm{mg} / \mathrm{kg})$ [44]. On the other hand, the study found the concentration of $\mathrm{Cu}$ in an edible mushroom ranged from 51.19 to $53.56 \mathrm{mg} / \mathrm{kg}$, higher than the maximum permitted limit $(0.05$ to $5 \mathrm{mg} / \mathrm{kg})$ $[50,52]$ and the mean concentration in fish accounted for $7.7 \mathrm{mg} / \mathrm{kg}$, which was lower than the allowable limit $(30.0 \mathrm{mg} / \mathrm{kg})$ [53]. And also, the study found the mean concentration of $\mathrm{Mn}$ in fruit and vegetables ranged from $0.26-869 \mathrm{mg} / \mathrm{kg}$ that was lower than the guideline $(500$ $\mathrm{mg} / \mathrm{kg}$ ) [54].

An excess amount of iron in the body 's tissues adversely affect immune function, cell growth, and heart health $[55,56]$. However, the current study found the mean concentration of Fe ranged from 199.5-370.4 mg/ $\mathrm{kg}$ in fruits and vegetables that was lower than the allowable limit (425.5 mg/Kg) [54], and 505.61-3549.9 mg/kg in the meat and milk that was higher than the maximum allowable limit $(100 \mathrm{mg} / \mathrm{kg})[46,57]$.

The maximum allowable concentration of $\mathrm{Ni}$ in fruit and vegetables ranged from $0.8 \mathrm{mg} / \mathrm{kg}$ for fruit [45] to $10 \mathrm{mg} / \mathrm{kg}$ for vegetables $[44,51]$. Similarly, the current study found the mean concentration of $\mathrm{Ni}$ in fruit and vegetables ranged from $1.037-5.27 \mathrm{mg} / \mathrm{kg}$ that was within the standard limit. However, the mean concentration of $\mathrm{Ni}$ in drinking water was 0.019 to $0.24 \mathrm{mg} / \mathrm{L}$ that was higher than guidelines, $0.07 \mathrm{mg} / \mathrm{L}[31,44]$.

Zinc is another metal which plays a vital role in the metabolic and physiological processes of many organisms and is important for growth and bone development. However, higher concentrations of $\mathrm{Zn}$ can cause poisoning in humans [31]. The current study found the overall mean concentration of $\mathrm{Zn}$ in fruit and vegetables ranged from $19.18-98.15 \mathrm{mg} / \mathrm{kg}$ that was less than the FAO/ WHO guideline $(99.4 \mathrm{mg} / \mathrm{kg})$. The concentration of $\mathrm{Zn}$ in fish and meat was ranged from $78.37-467.7 \mathrm{mg} / \mathrm{kg}$ that was higher than the allowable limit standard $(75 \mathrm{mg} /$ $\mathrm{kg}$ ), and $\mathrm{Zn}$ in edible mushrooms (89.68 to $95.26 \mathrm{mg} / \mathrm{kg}$ ) higher than the FAO/WHO, 2004 guideline $(0.3$ to $1 \mathrm{mg}$ / $\mathrm{kg}$ ) and in drinking water ranged from $0.625-2.137 \mathrm{mg} / \mathrm{L}$ that was higher than the guidelines $(0.2 \mathrm{mg} / \mathrm{L})$.

The higher concentration of heavy metals in foods and drinking water in Ethiopia may be due to the rise in waste discharged from industrial activities such as paper mill, textile, and leather industries, and use of untreated or partially treated waste water for agricultural purposes.

In general, the concentration of most heavy metals in foods and drinking water was higher than the maximum allowable limit that would be a health risk to the consumer associated with the consumption of these foods 
and drinking contaminated water. Therefore, we recommend a strict regulatory control on the safety of foods and industrial waste to be discharged to the environment as well as to be used for agricultural purposes.

\section{Limitations}

The review was based on previous studies that were conducted in different time periods. Therefore, the distribution may be incorrect. However, attempts were made to include all published articles on microbial quality and public health risk of ready-to-eat foods. Some important findings like conference proceedings and dissertations were not included in this study because of the type of search strategy adopted in this systematic review.

\section{Abbreviations}

FAO: Food and Agricultural Organization; JBI: Joanna Briggs Institute; MeSH: Medical Subject Headings; MMAT: Mixed methods appraisal tool; PRISMA: Preferred Reporting Items for Systematic Reviews and Meta-Analysis; SNNP: Southern Nation Nationality and People; WHO: World Health Organization

\section{Supplementary Information}

The online version contains supplementary material available at https://doi. org/10.1186/s12889-021-12189-3

\section{Additional file 1.}

\section{Acknowledgements}

I would like to extend my deepest thanks to Haramaya University, Department of Environmental Health staffs for providing their constructive support.

\section{Author's contributions}

DAM conducted this work independently. All activities in this work such as generating the idea, collecting and analyzing the data, writing, editing, revising, and approving the final version to be published were done by DAM

\section{Funding}

This review did not receive any specific funds.

\section{Availability of data and materials}

All data are included in the systematic review.

\section{Declarations}

Ethics approval and consent to participate

Not Applicable

\section{Consent for publication}

Not Applicable

\section{Competing interests}

There is no competing interest for this review.

Received: 2 December 2020 Accepted: 9 November 2021

Published online: 17 November 2021

\section{References}

1. Sobha K, Poornima A, Harini P, Veeraiah K. A study on biochemical changes in the fresh water fish, Catla catla (Hamilton) exposed to the heavy metal toxicant cadmium chloride. Kathmandu Univ J Sci Eng Technol. 2007;3(2):1. https://doi.org/10.3126/kuset.v3i2.2890.
2. Tadesse M, Tsegaye D, Girma G. Assessment of the level of some physicochemical parameters and heavy metals of Rebu river in oromia region, Ethiopia. MOJ Biol Med. 2018;3(4):99-118. https://doi.org/10.15406/mojbm.2018.03.00085.

3. Ikem A, Egiebor NO. Assessment of trace elements in canned fishes (mackerel, tuna, salmon, sardines and herrings) marketed in Georgia and Alabama (United States of America). J Food Compos Anal. 2005;18(8):77187. https://doi.org/10.1016/j.jfca.2004.11.002.

4. Lambert M, Leven BA, Green RM. New methods of cleaning up heavy metal in soils and water. Environmental science and technology briefs for citizens. Manhattan: Kansas State University; 2000.

5. Rahimi E. Lead and cadmium concentrations in goat, cow, sheep, and buffalo milks from different regions of Iran. Food Chem. 2013;136(2):389-91. https://doi.org/10.1016/j.foodchem.2012.09.016.

6. Hashemi M, Salehi T, Aminzare M, Raeisi M, Afshari A. Contamination of toxic heavy metals in various foods in Iran: a review. J Pharm Sci Res. 2017; 9(10):1692-7.

7. Prabu PC. Impact of heavy metal contamination of Akaki River of Ethiopia on soil and metal toxicity on cultivated vegetable crops. Electron J Environ Agric Food Chem. 2009;8(9):819-20.

8. Jaishankar M, Tseten T, Anbalagan N, Mathew BB, Beeregowda KN. Toxicity, mechanism and health effects of some heavy metals. Interdiscip Toxicol. 2014;7(2):60-72 https://doi.org/10.2478/intox-2014-0009.

9. Ali H, Khan E, Sajad MA. Phytoremediation of heavy metals-concepts and applications. Chemosphere. 2013;91(7):869-81. https://doi.org/10.1016/j. chemosphere.2013.01.075

10. Keraita B, Abaidoo RC, Beernaerts I, Koo-Oshima S, Amoah P, Drechsel P, et al. Safe re-use practices in wastewater-irrigated urban vegetable farming in Ghana. J Agric Food Syst Community Dev. 2012;2(4):147-58 https://doi. org/10.5304/jafscd.2012.024.004.

11. Ruma MM, Sheikh AU. Reuse of wastewater in urban farming and urban planning implications in Katsina metropolis, Nigeria. Afr J Environ Sci Technol. 2010:4(1):028-33.

12. Raschid-Sally L, Jayakody P. Drivers and characteristics of wastewater agriculture in developing countries: results from a global assessment. Colombo: International Water Management Institute (IWMI); 2009.

13. Ahmad K, Ashfaq A, Khan Zl, Ashraf M, Akram NA, Yasmin S, et al. Health risk assessment of heavy metals and metalloids via dietary intake of a potential vegetable (Coriandrum sativum L.) grown in contaminated water irrigated agricultural sites of Sargodha, Pakistan. Hum Ecol Risk Assess. 2016; 22(3):597-610. https://doi.org/10.1080/10807039.2015.1095630.

14. Zia MH, Watts MJ, Niaz A, Middleton DR, Kim AW. Health risk assessment of potentially harmful elements and dietary minerals from vegetables irrigated with untreated wastewater, Pakistan. Environ Geochem Health. 2017;39(4): 707-28. https://doi.org/10.1007/s10653-016-9841-1.

15. Adolf JNP, Azis BS. Microbiological status of various foods served in elementary school based on social-economic status differences in Karawachi region. Int Food Res J. 2012;19(1):65-70.

16. Yeung Ruth MW, Morris J. Food safety risk: consumer perception and purchase behavior. Br J Food. 2001;103(3):170-86. https://doi.org/10.1108/ 00070700110386728

17. Weldesilassie AB, Amerasinghe P, Danso G. Assessing the empirical challenges of evaluating the benefits and risks of irrigating with wastewater. Water Int 2011:36(4):441-54. https://doi.org/10.1080/02508060.2011.595056.

18. Hong QN, Pluye P, Fàbregues S, Bartlett G, Boardman F, Cargo M, et al. Mixed methods appraisal tool (MMAT), version 2018. Registration of copyright; 2018. p. 1148552. Available at http://mixedmethodsappraisa Itoolpublic.pbworks.com/.

19. The Joanna Briggs Institute. Critical appraisal tools for use in the JBI systematic reviews checklist for prevalence studies: The University of Adelaide. Available from: https://joannabriggs.org/sites/default/files/2019-05/JBI_Critical_Appraisa IChecklist_for_Prevalence_Studies2017_0.pdf. Accessed 2 Jan 2020.

20. Bahiru DB, Teju E, Kebede T, Demissie N. Levels of some toxic heavy metals $(\mathrm{Cr}, \mathrm{Cd}$ and $\mathrm{Pb})$ in selected vegetables and soil around eastern industry zone, Central Ethiopia. Afr J Agric Res. 2019;14(2):92-101. https://doi.org/10. 5897/AJAR2018.13324

21. Gebeyehu HR, Bayissa LD. Levels of heavy metals in soil and vegetables and associated health risks in Mojo area, Ethiopia. PLoS One. 2020;15(1): e0227883 https://doi.org/10.1371/journal.pone.0227883.

22. Marga AT. Assessment of selected trace elements in fruits and vegetables cultivated around Mojo, Meki and Zeway irrigation farms, Ethiopia. Intern Sci Res. 2016;5(4):863-6. https://doi.org/10.21275/v5i4.NOV162625. 
23. Bahiru DB, Teju E. Levels of some selected metals (Fe, Cu and Zn) in selected vegetables and soil around eastern industry zone, Central Ethiopia. Afr J Agric Res. 2019;14(2):78-91. https://doi.org/10.5897/AJAR2018.13615.

24. Gebrelibanos M, Megersa N, Taddesse AM. Levels of essential and nonessential metals in edible mushrooms cultivated in Haramaya, Ethiopia. Int J Food Contam. 2016:3(1):2. https://doi.org/10.1186/s40550-016-0025-7.

25. Gure A, Kedir K, Abduro F. Heavy metal concentrations in fish tissues from Gilgel Gibe (I) hydroelectric dam reservoir, Ethiopia. J Appl Sci Environ Manag. 2019;23(8):1411-6. https://doi.org/10.4314/jasem.v23i8.1.

26. Adefa T, Tefera M. Heavy metal accumulation and health risk assessment in Moringa Oleifera from Awi zone, Ethiopia. Chem Afr. 2020;(4):1-7. https:// doi.org/10.1007/s42250-020-00181-0.

27. Shitahun A, Tessema M. Determination of essential and toxic heavy metals in barley (Hordeum vulgare) cultivated in selected places in Amhara region, Ethiopia. Afr J Chem Educ. 2020;10(1):6-18.

28. Abebe A, Chandravanshi BS. Levels of essential and non-essential metals in the raw seeds and processed food (roasted seeds and bread) of maize/corn (Zea mays L.) cultivated in selected areas of Ethiopia. Bull Chem Soc Ethiop. 2017;31(2):185-99. https://doi.org/10.4314/bcse.v31i2.1.

29. Kindie M, Andargie M, Hilluf W, Amare M. Assessment on level of selected heavy metals in Nile tilapia and Barbus fish species and water samples from the southern parts of Lake Tana, Ethiopia. Sci Afr. 2020;9:e00519. https://doi. org/10.1016/j.sciaf.2020.e00519.

30. Gebrekidan A, Desta AA. Assessment on the levels of selected essential and non-essential metals in sesame seeds (Sesamum indicum L.) collected from Sheraro town, Northwest Tigray, Ethiopia. Bull Chem Soc Ethiop. 2019;33(2): 191-202. https://doi.org/10.4314/bcse.v33i2.1.

31. Haftu Z, Sathishkumar P. Determination of physicochemical parameters and heavy metals concentration in drinking water at Asgede Tsimbila District, Tigray, Ethiopia. Chem Afr. 2020;(2):1-8. https://doi.org/10.1007/s42250-02000129-4.

32. Mesfin Medihin Ododo. Physico-chemicals and heavy metals analysis of drinking water of Aksum University, Tigrai region, Ethiopia. J Phys Chem Sci. 2019;/771:05. https://doi.org/10.5281/zenodo.2572846.

33. Babuskin S, Yessuf AM, Hameed OB. Monitoring and assessment of the potential health risks associated with the toxic heavy metals content in selected fruits grown in Arba Minch region of Ethiopia. Int J Environ Anal Chem. 2020:1-2. https://doi.org/10.1080/03067319.2020.1790547.

34. Desalegn S, Israel L, Wouduma K. Analysis of physico-chemical properties and heavy metals content of drinking water from selected areas in Gurage zone, Ethiopia. Afr J Pure Appl Chem. 2018;12(2):9-13. https://doi.org/10. 5897/AJPAC2017.0729.

35. Abebe A, Chandravanshi BS, Debebe A. Assessment of essential and nonessential metals in popcorn and cornflake commercially available in Ethiopia. Chem Int. 2017:3:268-76.

36. Alamnie G, Menkir AK. Heavy metal contamination in green leafy vegetables irrigated with wastewater collected from Harartown vegetable farm, Ethiopia. Food Sci Qual Manag. 2020;94:24-8.

37. Gezahegn WW, Srinivasulu A, Aruna B, Banerjee S, Sudarshan M, Narayana $\mathrm{PL}$, et al. Study of heavy metals accumulation in leafy vegetables of Ethiopia. OSR J Environ Sci Toxicol Food Technol (IOSR-JESTFT). 2017;11(5): 57-68. https://doi.org/10.9790/2402-1105015768.

38. Yohannes W, Chandravanshi BS, Moges G. Assessment of trace metals and physicochemical parametres of commercially available honey in Ethiopia. Chem Int. 2018:4(2):91-101.

39. Haile E, Tesfau H, Washe AP, Werabe E. Determination of dietary toxins in selected wild edible plants of Ethiopia. Food Sci Qual Manag. 2018;75:1-9.

40. Akele ML, Abebe DZ, Alemu AK, Assefa AG, Madhusudhan A, de Oliveira RR. Analysis of trace metal concentrations in raw cow's milk from three dairy farms in North Gondar, Ethiopia: chemometric approach. Environ Monit Assess. 2017;189(10):499. https://doi.org/10.1007/s10661-017-6203-0.

41. Wilson B, Pyatt FB. Heavy metal dispersion, persistance, and bioccumulation around an ancient copper mine situated in Anglesey, UK. Ecotoxicol Environ Saf. 2007;66(2):224-31. https://doi.org/10.1016/j.ecoenv.2006.02.015.

42. Ametepey ST, Cobbina SJ, Akpabey FJ, Duwiejuah AB, Abuntori ZN. Health risk assessment and heavy metal contamination levels in vegetables from Tamale Metropolis, Ghana. Int J Food Contam. 2018;5(1):1-8. https://doi. org/10.1186/s40550-018-0067-0.

43. Broadhurst $\mathrm{CL}$, Domenico P. Clinical studies on chromium picolinate supplementation in diabetes mellitus - a review. Diabetes Technol Ther. 2006;8(6):677-87. https://doi.org/10.1089/dia.2006.8.677.
44. Joint $\mathrm{FAO} / \mathrm{WHO}$ food standards programme codex committee on contaminants in foods. InFifth Session [displayed 10 February 2014]. Available at ftp://ftp.fao.org/codex/meetings/CCCF/cccf5/cf05_INF.pdf. 21 Mar 2011.

45. WHO. Guidelines for drinking-water quality. 4th ed. Geneva: WHO; 2011. p. 307-433.

46. Tibebe D, Lemma D, Teshome G. Determination of heavy metals in Tilapia (Oreochromis Niloticus) and water samples from lake Hayq, South Wollo Ethiopia. Int J Chem Mater Res. 2019;7(1):10-9. https://doi.org/10.18488/ journal.64.2019.71.10.19.

47. Ezzati M, Lopez AD, Rodgers AA, Murray CJ. Comparative quantification of health risks: global and regional burden of disease attributable to selected major risk factors. Geneva: World Health Organization; 2004.

48. WHO. Guidelines for drinking-water quality. 3rd ed. Geneva: WHO; 2004.

49. Godt J, Scheidig F, Grosse-Siestrup C, Esche V, Brandenburg P, Reich A, et al. The toxicity of cadmium and resulting hazards for human health. J Occup Med Toxicol. 2006;1(1):1-6. https://doi.org/10.1186/1745-6673-1-22.

50. FAO/WHO. Codex Alimentariusdgeneral Standards for Contaminants and Toxins in Food. Schedule 1 Maximum and Guideline Levels for Contaminants and Toxins in Food. Reference CX/FAC 02/16. Rotterdam: Joint FAO/WHO Food Standards Programme, Codex Committee; 2002.

51. Shaheen N, Irfan NM, Khan IN, Islam S, Islam MS, Ahmed MK. Presence of heavy metals in fruits and vegetables: health risk implications in Bangladesh Chemosphere. 2016;152:431-8. https://doi.org/10.1016/j.chemosphere.2016. 02.060 .

52. Ihugba UA, Nwoko CO, Tony-Njoku FR, Ojiaku AA, Izunobi L. Heavy metal determination and health risk assessment of oyster mushroom Pleurotus tuberregium (Fr.) Singer, collected from selected markets in Imo State. Nigeria. Am J Environ Protect. 2018;6(1):22-7. https://doi.org/10.12691/env6-1-4

53. FAO/WHO. Joint FAO/WHO food standards programme CODEX committee on contaminants in foods. 5th ed. The Hague: Fernandes, C., FontaínhasFernandes; 2003.

54. Codex Alimentarius Commission. Food additives and contaminants. Joint FAO. WHO Food Stand Programme ALINORM. 2001;1:1-289. www.fao.org/ tempref/codex/Reports/Alinorm01/al01_12e.pdf.

55. Halliday JW. Hemochromatosis and iron needs. Nutr Rev. 1998;56(suppl_1): S30-7.

56. Gitet H, Hilawie M, Muuz M, Weldegebriel Y, Gebremichael D, Gebremedhin D. Bioaccumulation of heavy metals in crop plants grown near Almeda textile factory, Adwa, Ethiopia. Environ Monit Assess. 2016;188(9):500. https://doi.org/10.1007/s10661-016-5511-0.

57. FAO/WHO. Joint expert committee on food additives, fifty-ninth meeting, 2002. 2004. www.fao.org/es/ESN/Jecfa/59corr.pdf. Accessed 20 June 2017.

\section{Publisher's Note}

Springer Nature remains neutral with regard to jurisdictional claims in published maps and institutional affiliations.

Ready to submit your research? Choose BMC and benefit from:

- fast, convenient online submission

- thorough peer review by experienced researchers in your field

- rapid publication on acceptance

- support for research data, including large and complex data types

- gold Open Access which fosters wider collaboration and increased citations

- maximum visibility for your research: over $100 \mathrm{M}$ website views per year

At BMC, research is always in progress.

Learn more biomedcentral.com/submissions 